\title{
Survey and Collection of Insect Species Associated with Water Hyacinth on Ogun River, Nigeria
}

\author{
O. A. Oke ${ }^{1, *}$, A. M. Gbadebo ${ }^{2}$ \\ ${ }^{1}$ Department of Biological Sciences, University of Agriculture, Abeokuta, P. M. B. 2240 Nigeria \\ ${ }^{2}$ Department of Environmental Management and Toxicology, University of Agriculture, AbeokutaP.M.B. 2240,Nigeria
}

\begin{abstract}
The insect species found on water hyacinth plants were collected in each of the sampling station by using insect net on randomly selected ten water hyacinth per square meter of a floatable quadrant which was placed over the mat of water hyacinth on the water body. The collections were made on monthly basis for 18 months from October 2009 to March 2011. The insect species collected were grouped into five orders namely:Orthoptera; Coleoptera; Hemiptera; Odonata and Diptera. There were two families in the order Orthoptera: Pyrgomorphidrididae, andAcrididae. For the Pyrgomorphidae were Zonocerusvarigatus and Attractomorphaaurivilli, while in the Acrididae there was Oxyahyla. The order Coleoptera also had two families: Chrsomelidae and Lagriidae. Family Chrysomelidae had two genera: namelyLamprocopaoccidentalis and Leptaulacafissicollis. The family Lagriidae had only one species Lagriavillosa. The order Hemiptera was represented by only two families - Pentatomidae and Cercopidae. Only one genus was represented in the Pentatomidae - Aspaviaarmigera while the family Cercopidae had one species - Locrismaculatus. The order Odonata was represented by the family Libelludidae which has the genusAcisomapanorpoides. Lastly the order Diptera was represented by the family MusidaeMuscadomestica. The insect species performed different kinds of activities on the water hyacinth plants and these activities were performed to varying degrees or levels. These activities included tunnelling into the petioles of the water hyacinth, feeding on the leaf surfaces, mating on the water hyacinth, sucking the juice from the water hyacinth and resting or reposing on the water hyacinth. The result of this study has revealed that the insects present on water hyacinth on Ogunriver were not indigenous natural enemies of these water hyacinth plants because all the activities of these insects could not suppress the growth and proliferation of the water hyacinth, hence, the consequent rapid growth and propagation of the plant.
\end{abstract}

Keywords Survey, Collection, Insect, Identification and Natural Enemy

\section{Introduction}

Water has become a threat to the aquatic environment in many part of the world. Aquatic weeds such as water hyacinth, Eichhorniacrassipes (Marth) Solms, family Ponntedariacae; duckweed, Salvinia, water lilly, Nmphaea lotus; (Linn), Ceratopterissp, Azolla Africana, Pistiastratiotes (Linn); Paspalumpolystahydum(R. Br.); Ceratophyllumdermesum, Panicumsubalbidum (Kunth); Nymphellula (Desv.); affect water which is an important resource, by blocking canals and pumps in irrigation project, wasting water in evapotranspiration, hindering boat traffic, increaseing water-borne diseases, interfering with fishing and fish culture, and clogging rivers and canals so that drainage is impossible and floods result. See reference, as in[2]. This problem of aquatic weed growth is particularly severe in tropical nations were warm water and increasing numbers of dams and irrigation projects foster their growth. This pro-

* Corresponding author:

olubodeoke@yahoo.com (O. A. Oke)

Published online at http://journal.sapub.org/ijaf

Copyright (C) 2012 Scientific \& Academic Publishing. All Rights Reserved blem is worsened by increasing enrichment of natural waters by fertilizer runoff and nutrients from human and agricultural wastes.

Eichhorniacrassipesis considered to be the most problematic aquatic plant in several parts of the tropics and sub-tropics, especially in the developing countries with their increasing human population and shrinking water resources. See reference, as in[6].

Eichhorniacrassipesis now a serious aquatic problem throughout the tropical areas of the world, although this was not the case a century ago. It was virtually unknown outside of the neotropics until the 1880s. Almost simultaneous introductions of $E$. crassipesoccurred throughout the world in the half-century between 1880 and 1930 see reference, as in[5]. By the end of this period, it was established in such divers regions as Australia, India, South East Asia, Indonesia, Egypt, South Africa and United States. Because of this fast rate of propagation of dispersal and its broad ecological tolerance, it has become the most important plants species that challenges man's ability to harness the world's limited fresh water supplies. Failure to control this weed has fostered attempts to exploit it as a natural raw material for various purposes. 
The weed Eichhorniacrassipesentered Nigeria's lagoon system in 1984 see reference, as in[1]. It is capable of doubling its number in two weeks. This rapid growth rate of the weed, see reference, as in[3] has compelled an incessant interest in its control. It is known to obstruct fishing, water transportation, post-harvest food processing, recreation and a number of social needs for water by many riverine, lacustrine and estuarine communities.

\subsection{The Need for the Control of Water Hyacinth}

In virtually all areas where water hyacinth occurs as an aggressive alien element in fresh-water ponds, reservoirs, water ways and others, the plant causes a number of problems to man. Dense and large masses of the weed impede the flow of water in irrigation systems, prevent the free movement of boats and other navigations vessels, reduce the volume of available fresh water by increasing losses through evapo-transpiration, and compete with agricultural crops in cultivated areas. Also the water hyacinth impair the quality of water, cause serious disrupttions to aquatic life including fish and plankton, provide suitable habitat or food or both for molluscan and insect vectors of diseases like schitosomiasis and malaria, promote silting and gradual dying up of stagnant water bodies, and serve as alternative host of destructive organismslike crop pests and pathogens. Biological control of E. crassipes was first given serious attention in the United States in the 1960's. At that time a snail (Marisa $\underline{s p}$ ) and the West Indian Manatee (Trichechusmanatus) were even considered as possible biological control agents. In 1968, Perkins of the U. S. Department of Agriculture was assigned the task of determining if there were any insects on E. crassipesin its native range that might be useful as biological control agents. This led to concerted efforts on the biological control of $E$. crassipes.

\section{Objectives}

To know the insect pests associated with Water Hyacinth on Ogun River, Nigeria. Thereby to know if there is any insect which is a natural enemy to the Water Haycinth plants, and thereby serves as biological control of Water Hyacinth in Nigeria.

\section{Methods}

\subsection{The Study Sites}

\subsubsection{Location of Ogun River}

Ogun River stretches from Iganran Hills east of Shaki in the Northwestern part of Oyo State of Nigeria (latitude $07^{0}$ $40^{\prime} \mathrm{N}$ and longitude $03^{0} 35^{\prime} \mathrm{N}$ ) and flows southwards through Abeokuta in Ogun State, finally with its channel outlet into the Lagos Lagoon (latitude $06^{0} 30^{\prime} \mathrm{N}$ and longitude $03^{\circ} 20^{\prime} \mathrm{E}$ ), see reference, as in[9].

\subsection{Study Stations}

The study was conducted on the lower Ogun River Areas at Akute, Isasi, Iseri-Olofin, Orisa, and Idera, all near the Lagos Lagoon. A crescent-shaped dugout canoe with hired fishermen was used for the water transportation at each sampling station.

\subsection{Sampling Procedure}

Survey and Collection of Insect Species Associated with Water Hyacinth the insect species found on water hyacinth plants were collected in each sampling station by using insect net on randomly selected ten water hyacinth per square meter of a floatable quadrant which was place over the mat of water hyacinth on the water body. The collection was made on monthly basis for 18 months from October, 2009 to March, 2011. The insects were collected into labelled bottles. The collection were taken to the laboratory for sorting and identification.

\section{Results}

\subsection{Insect Species Inventory}

The insect species collected on water hyacinth at the study sites were grouped into five orders namely; Orthoptera; Coleopthera; Hemiptera, Odonata and Diptera. There were two families in the order Orthoptera: Pyrgomorphidae and Acrididae. For the Pymorphidae were Zonocerusvariegatus and Attractomorphaaurivilli, while in the Acrididae, there was Oxyahyla. The order Coleoptera also had two famimilies: Chnrysomelidae and Lagriidae. Family Chrysomelidae had two genera: namely Lamprocopaoccidentalis and Leptaulacafissicollis. The family Lacriidaehad only one species $L a-$ griavillosa. The order Hemiptera was represented by only two families - Pentatomidae and Cercopidae. Only one genus was represented in the Pentatomidae - Aspaviaarmigera while the family Cercopidae had one species Locrismaculata. The order Odonata was represented by the family Libellulidae which has the genus Acisomapanorpoides. Lastly the order Diptera was represented by the family Muscidae, Muscadomestica.

\subsection{Stages of Development and Density of Insect Species}

The different developmental stages of each insect species and their densities found on the Water hyacinth were noted. The stages of development of insects collected were the larvae, nymphs and adults. There were seasonal variations in the abundance of the larvae, nymphs and adults of the insect species. Low catch rate of the nymphs of Zonocerusvariegatus was obtained in February and March, 2010 and January, 2011. Nymphs of Attraxtomophaaurivilli were collected in January and May, 2010. While nymphs ofOxylahyla were obtained in November, 2009, February and June, 2010. Larvae of Lamprocopaoccidentalis were obntained in November, 2009; Lagriavillossa were obtained in July, 2010. Nymphs of Locrismaculata were obtained in 
March, 2010, August to October, 2010 and January, 2011. NymphsofAspaviaarmigera were obtained in January, 2010. Nymphs of Acisomapanorpoides were obtained in October, 2010.

\subsection{Location of Insect Species on Water Hyacinth}

The insect species were collected from different parts of the water hyacinth plant viz: the leaf surfaces, petioles and rhizomes. Zonocerusvariegatus, Attractomorphaaurivilli, Oxyahyla and Acrididae species were mainly on leaf surfaces throughout the period of the study. Lamprocopaoccidentalis, Leptaulacafissicollis, Lagrivillosa, Locrismaculata, Aspaviaarmigera, Acisomapanorpoides and Muscadomestica were found on the leaf surfaces, petioles and rhizomes. Larvae of Lamprocopaoccidentalis and Leptaulaca of Lamprocopaoccidentalis and Leptaulacafissicollis were found tunneling in the petiole of water hyacinth.

\subsection{Activities and Degree of Activities of Insect Species}

The insect species performed different kind of activities on the water hyacinth plants and these activities were performed to varying degrees or levels. The activities performed included tunnelling into the petioles of the water hyacinth, feeding on the leaf surfaces, mating on the water hyacinth, sucking the juice from the water hyacinth and resting on the water hyacinth.

\section{Discussion}

In this study, the insect species performed different kind of activities on the water hyacinth. These activities include feeding, resting, sucking, visit flowers, mating and tunneling into the petiole of the water hyacinth. Larvae, nymphs and adult of the insect species feed preference was on the upper leaf surface, lower leaf surface and the petiole of water hyacinth. See reference, as in[14] reported that viable growing macrophytes were considered as food resource for most macro-invertebrates). Arthropods associated with water hyacinth and their activities reported from other countries included Cornopsaquaticum Bruner adult and nymph fed on leaf surface in Uruguay and Argentina see reference, as in [13] and [10], [4] reported that Tetrataeniaphila Rehn (Acrididae) adult and nymph fed leaf surface, laid eggs in petiole in Surinam and Brazil. See reference, as in[4] reported that Phlugustere De Geer (Tettigonidae) adult oviposited in stem in Thailand.

\subsection{Non-Existence of Indigenous Natural Enemies of Water Haycinth on Ogun River, Nigeria}

Without the natural enemies, plants and animals may multiply unchecked thus becoming serious pests. In its native habitats of South America (Brazil, Guyana and Argentina), water hyacinth does not compete seriously with man because indigenous insects like Sameodesalbigutalis Warren, AcigomainfusellaWalker, Neochetinabruchi Husta- che; fungi likePenicillumoxalicum, Curvularialunatafusarium sp. Trichodermaviride, Myrotheciumroridum, Aspergillusniger, Cunninhamelia sp. and Cladeosporium sp. and other natural enemies restrain its growth, see reference, as in[12]. See reference, as in[11] reported that certain plant pathogens like Alternariaeichhornia, Cercosporarodmanu and infect water hyacinth Acremoniumzonatum and contribute to a reduction in the weed infestation.

\section{Conclussions}

The result of this study has revealed that the insects present on water hyacinth on Ogun river were not indigenous natural enemies these water hyacinth plants because all the activities of these insects could not suppress the growth and proliferation of the water hyacinth, hence the consequent rapid growth and propagation of the plant. Therefore, the search for exotic natural enemies of water hyacinth in Nigeria became essential and imperative, realizing the fast rate at which this plant is invading our coastal and inland water - ways.

\section{AKNOWLEDGEMENTS}

The authors acknowledged the assistance of Mr. K. M. Makinde for type-setting the manuscript.

\section{REFERENCES}

[1] Akinyemiju, O. A. and A. M. A. Imevbore (1990). Herbicidal control of water hyacinthin Nigeria - A field pilot demonstration at Kofawei creek, Igbokoda, Ondo State. A final report submitted to the Presidency, Federal Republic of Nigeria, Lagos, 181pp

[2] Anonymous (1980). Making aquatic weeds useful.Some perspective for developing countries

[3] Batanouny, K. H. and A. M. El-Fiky (1975). The water hyacinth (EichhorniacrassipesSolms) in the Nile system, Egypt.Aquatic Botany 11, pp 243-252

[4] Bennett, F. D. and H. Zwolfer (1968). Exploration for Natural Enemies of water hyacinth in Northern South America and Trinidad.Hyacinth Control Journal 7: 44-52

[5] Center, T. D. and J. K. Balciunas (1982). Water hyacinth in the United States.In report of the Regional Workshop on biological control of water hyacinth, Bangalore, India.Commonw. Sci. Council. Pp 57-62

[6] Gopal, B. and K. P. Sharma (1981). Water hyacinth (Eichhorniacrassipes) most troublesome weed of the world. Delhi: Hindasia Publishers. 128pp

[7] Harley, K. L. S. (1977). Biological control of aquatic weed.Pp.77-87, in the menace of water hyacinth and other aquatic weeds.Proc.Of a Symposium. Water Research Foundation of Australia, Adelaide 
[8] Huffaker, C. B. (1978). An overview of biological control with particular comments on biological weed control.Proc. IV Int. Symp. Biol. Control. Weeds (Ed. T. E. Freeman): 3-12. Univ. Florida, Gainesville

[9] Oshun River Basin master plan for development of water resources.Ogun - Oshun River Basin Development Authority (1980) draft final report

[10] Perkins, B. D. (1974). Arthropods that stress water hyacinth.PestArtic.NewsSumm. 20: 304-314

[11] Sankaran, T. (1982). Methods of control of water hyacinth, including biological control.Report of the regional workshop on biological control of water hyacinth. Bangalore, India
[12] Seng, O. K. (1982). Management and control of water hyacinth in Malaysia. Report of the regional workshop on biological control of water hyacinth in Bangalore, India on 3 5 May, 1982: pg. 45-48

[13] Silveira-Guido, A. (1965). Natural enemies of weed plants, Final report; Dept. Sanidad Vegetal, Univ. de la Republican Montedideo, Uruguay, Unpubl.Mimeogr. 128pages

[14] Sozka, G. J. (1975). The invertebrate on submerged macrophytes in threeMasurianLakes.Ekol. Pol 23: 371-391

[15] Thyagarajan, G. (1982). Water hyacinth problem or potential crop.Report of the regional workshop on biological control of water hyacinth. Bangalore, India 